\title{
KAJIAN LITERATUR WAREHOUSE 4.0 : DAMPAK INDUSTRI 4.0 TERHADAP MANAJEMEN PERGUDANGAN
}

\section{Nyoman Purnaya}

Institut Ilmu Sosial dan Manajemen STIAMI

Fakultas Ilmu Sosial dan Manajemen

Manajemen Logistik

Email : nyoman@stiami.ac.id

\section{ARTICLE INFO}

\section{Kata Kunci:}

manajemen pergudangan, industri 4.0, logistik 4.0, warehouse 4.0

\section{ABSTRACT}

Industri 4.0 telah memberikan dampak pada sektor pendukung inti dari industri, yaitu sektor logistik, dan pergudangan merupakan bagian penting dalam aliran bahan baku dan hasil produksi hingga pengguna akhir, dimana pergudangan telah menjadi sumber kunci dalam mencapai keunggulan kompetitif dari organisasi penyedia jasa logistik, maupun distribusi.

Artikel ini berfokus pada pembahasan dampak dari paradigma industri 4.0 terhadap manajemen pergudangan, dan selanjutnya penelitian ini lebih banyak mendiskusikan mengenai aplikasi teknologi pada manajemen pergudangan, disebut sebagai Warehouse 4.0. Pembahasan hasil penelitian dan diskusi dalam artikel ini diperoleh berdasarkan studi literatur dari berbagai tipe literatur yang menjadi sumber-sumber data, diantaranya artikel-artikel ilmiah, website-website perusahaan, hasil laporan konsultan, dan blog. Banyak manfaat yang dapat diidentifikasi dari warehouse 4.0 dengan implementasi IoT\&S pada manajemen pergudangan diantaranya, pengawasan dari ujung ke ujung mengenai pergerakan persediaan, pencatatan jumlah persediaan terkini, peringatan awal tentang perbedaan antara data persediaan pada sistem ERP dengan aktual di gudang, data penerimaan persediaan terkini dari sensor penerimaan yang dapat memastikan akurasi pengukuran tingkat persediaan. 


\section{PENDAHULUAN}

Meskipun sampai saat ini definisi indutri 4.0 belum ditentukan secara meyakinkan, namun perkembangan teknologi telah mengubah paradigma industri yang disebut revolusi industrial. Industri 4.0 yang akan meningkatkan dan mengubah kegiatan logistik tradisional dan persepsi-persepsinya.

Beberapa penelitian menyebutkan, industri 4.0 telah memberikan dampak pada sektor pendukung inti dari industri, yaitu sektor logistik. Wang, K (2016) menjabarkan mengenai evolusi logistik yang pertama ditandai dengan inovasi yang dipicu oleh mekanisasi transportasi pada akhir abad ke 19 hingga awal abad 20. Kedua, ditandai dengan adanya inovasi yang dikendalikan oleh otomasi sistem penanganan barang dari tahun 1960an. Ketiga, direpresentasikan dengan inovasi pada sistem pengelolaan logistik yang dimulai pada tahun 1980an. Kini, evolusi logistik ditandai dengan inovasi yang dikendalikan oleh Internet of Things and Services (IoT\&S).

Menurut Barreto, L. et al (2017), logistik 4.0 merujuk pada penggunaan kombinasi antara aplikasi yang ditambahkan Cyber-Physical System (CPS) dan inovasi teknologi, untuk menjalankan aktivitasaktivitas yang bersifat pengulangan dan otomasi.

Sebagai bagian dari aktivitas logistik, pergudangan merupakan bagian penting dalam aliran bahan baku dan hasil produksi hingga pengguna akhir, dimana pergudangan telah menjadi sumber kunci dalam mencapai keunggulan kompetitif dari organisasi penyedia jasa logistik, maupun distribusi.

Artikel ini berfokus pada pembahasan dampak dari paradigma industri 4.0 terhadap manajemen pergudangan, dan selanjutnya penelitian ini lebih banyak mendiskusikan mengenai aplikasi teknologi pada manajemen pergudangan atau dapat disebut sebagai Warehouse 4.0,

\section{METODE PENELITIAN}

Pembahasan hasil penelitian dan diskusi dalam artikel ini diperoleh berdasarkan studi literatur dari berbagai tipe literature yang menjadi sumber-sumber data, diantaranya artikel-artikel ilmiah, websitewebsite perusahaan, hasil laporan konsultan, dan blog.

Memahami ruang lingkup aktivitas manajemen pergudangan menjadi langkah awal untuk mengidentifikasi dampak industri 4.0 terhadap aktivitas-aktivitas manajemen pergudangan. Melakukan analisis dampak industri 4.0 pada setiap aktivitas manajemen pergudangan. Selanjutnya mendiskusikan peluang dan tantangan implementasi teknologi pada setiap aktivitas pergudangan.

\section{HASIL PENELITIAN}

\subsection{PEMAHAMAN INDUSTRI 4.0}

Oleh karena terminologi Industri 4.0 belum didefiinisikan secara pasti, namun secara umum membahas empat fitur utama, diantaranya: jejaring vertikal dari sistem produksi pintar, yang berbasis Cyber-Physical System (CPS). Integrasi horizontal melalui generasi terbaru dari jaringan rantai nilai 
global. Melalui dukungan rekayasa kehidupan kesluruh rantai nilai. Akselerasi melalui teknologiteknologi eksponensial. (Tjahjono, B. et al, 2017).

Cyber-Physical System (CPS) merupakan sistem rekayasa dan fisik, dimana operasional dapat diawasi, dikoordinasikan, dikendalikan dan teringrasi mempergunakan sistem komunikasi dan komputerisasi.

Industri 4.0 bertujuan untuk membantu perkembangan jejaring cerdas dari proses dan produk yang dihasilkan sepanjang rantai nilai, sehingga mempermudah organisasi untuk lebih efisien dalam melakukan proses produksi dan menawarkan keuntungan yang lebih banyak bagi konsumen.

Tujuan utama industri 4.0 adalah mengintegrasikan digital manufaktur - disebut pabrik pintar - dengan pemasok dan konsumen yang mengadopsi model bisnis inovasi. Pabrik pintar yang dimaksud adalah jejaring pintar, fleksibilitas operasional dan interoperabilitas.

\subsection{PEMAHAMAN LOGISTIK 4.0}

Logistik 4.0 (Wang, K. 2016) merupakan terminologi kolektif untuk teknologi-teknologi dan konsep-konsep dari rantai nilai organisasi. Penerapan dan proses-proses logistik 4.0 secara menyeluruh di dalam organisasi, merupakan karakteristik dasar dari logistik 4.0 itu sendiri.

Tiga perubahan dalam logistik dalam beberapa tahun terakhir, disebutkan sebagai evolusi logistik. Inovasi yang ditandai dengan adanya mekanisasi transportasi yang terjadi pada akhir abad ke-19 dan awal abad ke-20 disebut sebagai logistik 1.0. Inovasi yang digerakkan oleh otomasi sistem penanganan barang yang terjadi pada tahun 1960an disebut sebagai logistik 2.0. Inovasi pada sistem manajemen logistik yang dimulai pada tahun 1980an disebut sebagai logistik 3.0. Hingga kini, dengan adanya Internet of Things and Service (IoT\&S) dan big data yang berimplikasi pada logistik, dikatakan sebagai logistik 4.0.

Tujuan utama dari logistik 4.0 adalah penghematan tenaga kerja dan standarisasi pada manajemen rantai pasok. Manajemen rantai pasok akan menjadi jejaring yang sangat besar, dimana seluruh pemangku kepentingan pada rantai pasok akan terlibat - dari pemasok hingga konsumen akhir.

Seluruh aktivitas di dalam logistik akan diterima berdasarkan informasi yang berasal dari internet platform yang dapat digunakan oleh seluruh pemangku kepentingan. Sehingga penerimaan pesanan dari pemasok atau konsumen dapat kelola secara daring dan terkini.

\subsection{PEMAHAMAN WIREHOUSE 4.0}

Gudang akan selalu menjadi terminal yang vital di dalam aliran barang pada rantai pasok, sehingga manajemen cerdas yang diadopsi dan diimplementasikan dengan benar berdasarkan paradigma industri 
4.0, akan mengubah sistem manajemen pergudangan, sebagai persyaratan inbound logistics di masa depan.

Sehingga tujuan dari warehouse 4.0 adalah menghemat biaya-biaya pergudangan menjadi minimal atau bahkan dihilangkan, oleh karena pesanan-pesanan dari konsumen ataupun dari pemasok diproses pada waktu yang bersamaan.

Implikasi industri 4.0 dalam manajemen pergudangan diidentifikasi sebagai komponen-komponen teknis logistik 4.0 (Wang, K. 2016), dimana secara mendasar akan mengubah aktivitas-aktivitas manajemen pergudangan menjadi warehouse 4.0.

Teknologi otomasi identifikasi (automation identification) dikembangkan sebagai teknologi otomasi pengumpulan data berbasis teknologi komputer. Teknologi otomasi identifikasi diaplikasikan dalam bentuk teknologi bar-code, teknologi smart-card, radio frequency identification (RFID).

Teknologi pengalokasian terkini (Real-time locating systems) diaplikasikan untuk mengidentifikasi secara otomatis dan melacak lokasi barang tersimpan secara terkini.

Teknologi pemindai cerdas (smart sensing) dipergunakan untuk mendeteksi kondisi barang atau perubahan lingkungan yang terjadi disekitar barang tersebut, kemudian diinformasikan sebagai dasar pengambilan keputusan.

Teknologi jejaring (networking) menjadi sarana vital untuk menghubungkan antar peralatan dan komponen yang memungkinkan dalam pengambilan, pengumpulan dan pertukaran data.

\section{PEMBAHASAN DAN DISKUSI}

Internet of Things and Service (IoT\&S) dan big data yang diadopsi dari logistik 4.0 dalam manajemen pergudangan akan mengubah aktivitas-aktivitas pengelolaan pergudangan, dimana IoT\&S mengintegrasikan perangkat elektronik dengan sistem komputer yang memberikan kejelasan pada proses operasional.

\subsection{PERGERAKAN PERSEDIAAN}

Tantangan mendasar dalam manajemen pergudangan yaitu pengelolaan pergerakan persediaan. Pencatatan data penerimaan secara manual ke dalam sistem enterprise resource planning (ERP), kesalahan-kesalahan pengukuran dalam pengumpulan data dari gudang, terjadinya penundaan pengumpulan data pengiriman persediaan dari gudang, data persediaan in-transit tidak diperoleh secara terkini, dan banyak aktivitas lainnya, memungkinkan terjadinya ketidakakuratan data yang tersaji pada sistem ERP.

IoT\&S menghubungkan seluruh bagian-bagian yang bergerak dalam pengelolaan pergudangan, dari proses penerimaan di gudang hingga pergerakan penerimaan yang dilakukan oleh konsumen. IoT\&S 
mampu mencegah terjadinya kerusakan dan kehilangan barang, juga memberikan informasi lebih dari sekedar lokasi penempatan barang. Melakukan pengawasan terhadap masa kadaluwarsa suatu barang, sehingga mempermudah dalam pengambilan keputusan, yang akan berdampak pada peningkatan kualitas barang untuk pemenuhan kebutuhan konsumen.

\subsection{PENERIMAAN PERSEDIAAN}

Aktivitas penerimaan persediaan yang diawali dengan proses bongkar (unload), pemeriksaan kualitas (kondisi, jumlah), dan pencatatan data penerimaan, dipermudah dengan mengimplementasikan smart sensing.

Sensor pada pada proses penerimaan akan menangkap data persediaan yang masuk dan memberikan umpan/pencatatan yang sama pada IoT\&S yang tersimpan pada server.

\subsection{PENEMPATAN PERSEDIAAN}

Aktivitas penempatan persediaan dalam pengelolaan gudang diawali dengan mengidentifikasi persediaan, pengidentifikasian lokasi penyimpanan, dilanjutkan dengan pergerakan persediaan menuju lokasi yang telah diidentifikasi, dan diakhiri dengan pemutakhiran pencatatan.

Implementasi IoT\&S pada aktivitas pengaturan penempatan persediaan diawali dengan identifikasi persediaa dan akan memberikan lokasi yang tepat serta menempatkan persediaan pada lokasi penyimpanan sesuai peruntukkannya. Kemudian secara otomatis melakukan pemutakhiran data pada sistem ERP.

\subsection{LOKASI PENYIMPANAN}

IoT\&S membantu dalam mengoptimalkan pemanfaatan dan pengelolaan ruang (space) dan lokasi penyimpanan persediaan, Aplikasi barcode, quick response code ( $\mathrm{QR}$ code) akan membantu kemampuan dalam menelusuri persediaan sesuai dengan klasifikasinya dalam periode tertentu mingguan dan bulanan. IoT\&S juga mampu menelusuri persediaan dengan mempergunakan perangkat drone atau Automatic Guide Vehicle (AVG) secara rutin. Sensor yang diaplikasikan pada perangkatperangkat IoT\&S akan mengidentifikasi dan mencatat pemanfaatan ruang (space) secara fisik.

\subsection{PENGAMBILAN PESANAN}

Diawali dengan pengumpulan informasi pemesanan, pengaturan pengambilan persediaan dan pengambilan fisik persediaan, dapat diatur secara otomatis dengan mengimplementasikan IoT\&S. IoT\&S akan mencari gudang virtual untuk memesan persediaan dan mengatur tenaga kerja atau AVG yang dikendalikan dengan data. IoT\&S mengarahkan tenaga kerja atau AVG untuk mengambil persediaannya yang sesuai dengan permintaan. 


\subsection{PERSIAPAN PENGIRIMAN}

Verifikasi akurasi sebelum pengepakan pesanan dilakukan dengan aplikasi IoT\&S, dilanjutkan dengan proses penandaan paket-paket dengan benar sebagai informasi pengiriman. Persiapan pengiriman menentukan kualitas pengiriman dan menjamin kualitas penyampaian pesanan dari konsumen. IoT\&S akan menelusuri pergerakan persediaan dari proses pemesanan hingga penerimaan oleh konsumen.

\subsection{PENGIRIMAN CERDAS}

Implementasi IoT\&S akan mengidentifikasi kendaraan yang tepat dan sesuai untuk setiap pemesanan, serta melakukan penelusuran pergerakan dari proses pengiriman mempergunakan global positioning system (GPS), dan memperbaharui data kedalam database penelusuran. Data dan informasi dalam proses pengiriman yang berupa jadwal pengangkutan, berat dan beban kendaraan, surat muatan dan pemutakhiran pencatatan, akan terkumpul dalam waktu terkini, sehingga dapat menghilangkan terjadinya ketidakuratan pencatatan pada sistem ERP.

\section{SIMPULAN}

Logistik 4.0 merupakan bagian dari industri 4.0 dan akan meningkatkan perkembangan industri 4.0 itu sendiri. Demikian pula warehouse 4.0 merupakan bagian dari logistik yang terdampak dari industri 4.0 yang menentukan terjadinya efisiensi, fleksibilitas, dan keterhubungan dengan jejaring.

Banyak manfaat yang dapat diidentifikasi dari warehouse 4.0. Implementasi IoT\&S pada manajemen pergudangan diantaranya, pengawasan dari ujung ke ujung mengenai pergerakan persediaan, pencatatan jumlah persediaan terkini, peringatan awal tentang perbedaan antara data persediaan pada sistem ERP dengan aktual di gudang, data penerimaan persediaan terkini dari sensor penerimaan yang dapat memastikan akurasi pengukuran tingkat persediaan. 


\section{DAFTAR PUSTAKA}

[1] Barreto, L., Amaral, A., Pereira, T. Industry 4.0 implication in logistics: an overview. ScienceDirect, Procedia Manufacturing 13, 2017.

[2] Tjahjono, B., Esplugues, C., Ares, E., Pelaez, G. What does Industry 4.0 mean to Supply Chain?. ScienceDirect, Procedia Manufacturing 13, 2017.

[3] Wang, K. Logistics 4.0 Solution: New Challenge and Opportunities. International Workshop of Advances Manufacturing and Automation. 2016

[4] https://www.clearspider.com/blog-warehouse-technology-internet-of-things/

[5] https://www.softwareag.com/kr/Images/IoT\%20enabled\%20Smart\%20Warehouse\%20Solution_t cm416-169456.pdf 